\title{
High gain boost converter with modified voltage multiplier for stand alone PV system
}

\author{
P. Getzial Anbu Mani, A. K. Parvathy \\ Hindustan Institute of Technology and Science, India
}

\begin{tabular}{l}
\hline \hline Article Info \\
\hline Article history: \\
Received Aug 9, 2018 \\
Revised Nov 28, 2018 \\
Accepted Jan 7, 2019 \\
\hline
\end{tabular}

\section{Keywords:}

High voltage conversion ratio Interleaved boost converter Reduced input current ripple Reduced voltage stress

\begin{abstract}
Boost converters of high gain are used for photo voltaic systems to obtain high efficiency. These high gain Boost converters gives increased output voltage for a low input $t$ voltage. The High gain boost converters have the following merits. Conduction losses input current ripple and stress across the switches is reduced while the efficiency is increases. The high gain of the converters with the above said merits is obtained by changing the duty cycle of switches accordingly .In this paper a boost converter working with interleaved concept along with a additional $\mathrm{N}$-stage voltage Multiplier has been carried out by simulation using MATLAB/simulink and the mathematical modeling of various parameters is also done.
\end{abstract}

Copyright $(2019$ Institute of Advanced Engineering and Science. All rights reserved.

\section{Corresponding Author:}

P. Getzial Anbu Mani,

Hindustan Institute of Technology and Science,

No, 1 Rajiv Gandhi Salai Padur 603103, India.

Email: getzialam@hindustanuniv.ac.in

\section{INTRODUCTION}

Non-conventional energy systems are becoming more efficient and affordable .These Renewable Energy sources is helping in increasing the energy security on an indigenous, inexhaustible and most importantly an independent source. It also increases the sustainability, reduce pollution and decrease the fossil fuel cost.

Solar power is the best reliable energy source when compared with other renewable sources. Once installed they require less maintenance with a considerable less pollution. A photovoltaic converts light energy into electric direct current energy. Photo voltaic is nowadays is used as a fast growing energy producing plant by continuous improvement in installation cost reduction.

Renewable energy systems produce low output voltage. Hence high gain dc-dc converters are used to increase the low input voltage to boosted output voltage. The output obtained from such high gain boost converters are fed to a suitable inverter which converts the dc voltage to ac voltage and used by ac loads. Figure 1 shows the block diagram of Stand Alone PV system. It shows the basic units required for the conversion of light energy into usable ac and dc power.

Boost converters are the basic converter topology for achieving increased output. A single photo voltaic panel can only produce $15-45 \mathrm{~V}$ dc that has to be stepped up to $400 \mathrm{~V} \mathrm{dc}$. An interleaved boost converter with coupled inductors and clamping capacitors are the emerging design technic used to increase the voltage output [1]. The conventional interleaved boost converter can be used for high-power applications and power factor correction [2], [4]. But these converters have some difficulty in obtaining stepped up voltage. Only with 0.9 duty cycle a boost converter produces high voltage gain which results in instability of the converter [3], [6], [8], [9] .Unfortunately, the voltage conversion ratio (i.e) the gain is limited and the voltage stresses across power switches are equal to output voltage [10]. The first section explains the 
interleaved converter with modified voltage multiplier module ,the second section explains the modes of operation and the third section shows the design calculations along with the simulation results.

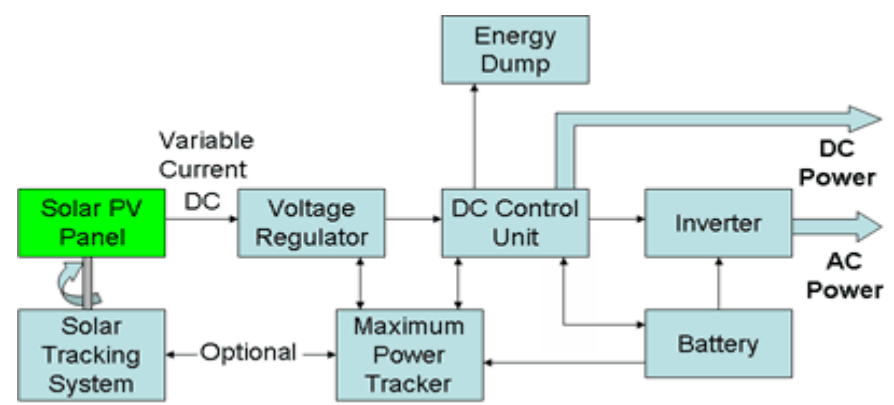

Figure 1. Block diagram of Stand Alone PV system

\section{PROPOSED DC-DC CONVERTER TOPOLOGY}

The proposed topology is an Interleaved Boost converter with modified voltage multiplier as shown in Figure 2. This combines the interleaved boost converter, the coupled inductor and switched capacitor function to provide the require output voltage at the desired power level. The modified topology is a two switch design, employing two coupled inductors, capacitors and diodes for an $\mathrm{N}$ stage voltage multiplier. The main advantages of this topology are (1) high gain without transformers; (2) two switch topology; (3) continuous input current (4) easily expanded to give higher voltage gain.

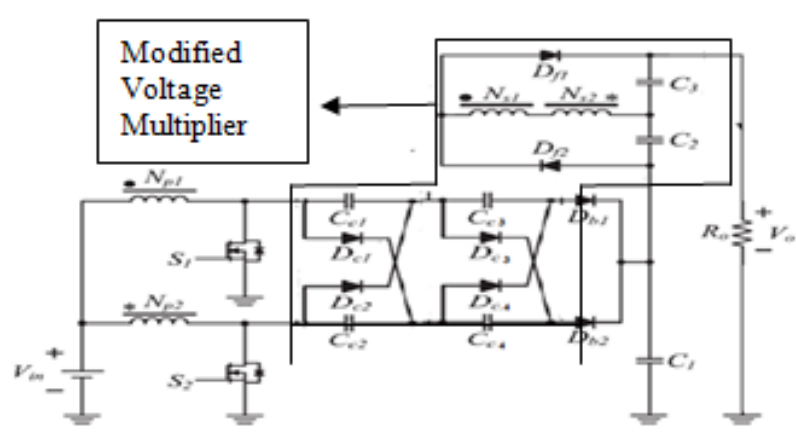

Figure 2. Circuit Diagram of Interleaved Converter with Modified Voltage Multiplier

\section{MODES OF OPERATION}

Operation principle of this converter is same as the converter with interleaving concept along with a voltage multiplier. The voltage multiplier is modfied by adding one stage of voltage multiplier along with the existing topology. The multiplier circuit consisting of two feedback diodes and four clamping capacitors, is inserted between conventional interleaved boost converters and output side to form a modified interleaved boost converter. During switch OFF condition it works like fly back converter, and when switch is in ON condition works as a forward converter. The operating modes are shown in Figure 3 and explanation is given below.

MODE I:

The switching operation of the power switches are as shown in Mode I as in Figure 3(a) circit diagram.Inductor Lm1 continues to charge the coupled inductors. The stored energy in the leakage inductance Ls is supplied to the output terminal via a feedback diode Df2 which is alone forward biased.

MODE II:

The switches and diodes conductions are as shown in Figure 3(b). Since the switches are in ON state the voltage source Vin is fed to the leakage inductors $\mathrm{L}_{\mathrm{k} 1}$ andL $\mathrm{L}_{\mathrm{k} 2}$. Hence the current through them increases linearly. 


\section{MODE III:}

In this mode the switch $\mathrm{S}_{1}$ is still ON and switch $\mathrm{S}_{2}$ begins to turn OFF. The clamping capacitor $\mathrm{C}_{\mathrm{cl}}$ and $\mathrm{C}_{\mathrm{c} 3}$ clamps the potential on the switch $\mathrm{S}_{2}$. The output voltage of the boost converter is doubled due to the energy transfer from input voltage (Vin), inductors $\mathrm{L}_{\mathrm{m} 2}, \mathrm{~L}_{\mathrm{k} 2}$ and capacitors $\mathrm{C}_{\mathrm{c} 2}, \mathrm{C}_{\mathrm{c} 4}$.

MODE IV:

The distribution of current in the magnetizing circuits helps the current ini $\mathrm{D}_{\mathrm{Dc} 2}$ decrease to zero naturally.Both power switches and all diodes remain in previous states except the clamp diode $\mathrm{D}_{\mathrm{c} 2}$, as shown in Figure 3(d)

MODE V:

The switching of switches and the biasing of diodes is as shown in Figure 3(e). The load across the output terminal is fed with the energy released from the series inductance $\mathrm{L}_{\mathrm{s}}$ through diode $\mathrm{D}_{\mathrm{fl}}$. The secondary side of the winding $\mathrm{N}_{\mathrm{s} 1}$ and $\mathrm{N}_{\mathrm{s} 2}$ receives energy from $\mathrm{L}_{\mathrm{m} 2}$. The currents in leakage inductors $\mathrm{L}_{\mathrm{k} 2}$ and $\mathrm{L}_{\mathrm{k} 1}$ increases and decreases respectively.

MODE VI:

The power electronic switches are still in ON condition and biasing of the diodes is as shown in Figure 3(f). Inductors $L_{k 1}$ and $L_{k 2}$ increases linearly by the input supply voltage.

MODE VII:

The switching of the power switches is same as that of mode I. The diodes that are in reverse biased, are shown in Figure $3(\mathrm{~g})$. The energy stored in inductor $\mathrm{L}_{\mathrm{m}}$ is mutually transferred to the secondary side inductor windings $\mathrm{N}_{\mathrm{s} 1}, \mathrm{~N}_{\mathrm{s} 2}$. The current in inductor $\mathrm{L}_{\mathrm{s}}$ is passed through the capacitor $\mathrm{C}_{2}$ to the output terminal via diode $\mathrm{D}_{\mathrm{f} 2}$. The clamping capacitor $\mathrm{C}_{\mathrm{c} 2}$ reduces the switch voltage stress of switch $\mathrm{S}_{1}$. The input voltage source, magnetizing inductor $\mathrm{L}_{\mathrm{m} 1}$, the inductor $\mathrm{L}_{\mathrm{k} 1}$, and clamp capacitor $\mathrm{C}_{\mathrm{c} 1}, \mathrm{C}_{\mathrm{c} 3}$ discharges the stored energy MODE VIII:

The diode currents $i_{\mathrm{dcl}}$ and $i_{\mathrm{dc} 3}$ is reduced to zero This contributes to much reduction in conduction losses and the diode reverse recovery is completely nullified. Except for the clamping diodes $D_{c 1}$ and $D_{c 3}$ the switches and the other diodes remain in the preceding condition, as shown in Figure 3(h).

\section{MATHEMATICAL ANALYSIS}

\subsection{Output Voltage Gain}

The output voltage is same as the voltage across the clamping capacitors $\mathrm{C}_{\mathrm{c}}$. It is given by,

$\mathrm{V}_{\mathrm{C}_{\mathrm{c}}}=\frac{2}{1-\mathrm{D}} \mathrm{V}_{\mathrm{in}}$

Hence:

The voltages across the $\mathrm{C}_{1}$ and $\mathrm{C}_{2}$ are obtained using the principle of inductor voltage-second balance.

$\mathrm{V}_{\mathrm{C} 1}=\frac{2}{1-\mathrm{D}} \mathrm{V}_{\text {in }}+\mathrm{V}_{\mathrm{C}_{\mathrm{c}}}=\frac{4}{1-\mathrm{D}} \mathrm{V}_{\text {in }}$

The energy in the coupled inductors $\mathrm{N}_{\mathrm{p} 1}$ and $\mathrm{N}_{\mathrm{p} 2}$ are used to charge the filtering capacitors $\mathrm{C}_{2}$ and $\mathrm{C}_{3}$ at the output. When power switch $S_{2}$ is in ON condition, the filter capacitor voltage $\left(V_{C 2}\right)$ is equal to the voltages induced in $\mathrm{N}_{\mathrm{S} 1}$ and $\mathrm{N}_{\mathrm{S} 2}$. Similarly when the power switch $\mathrm{S}_{1}$ is in $\mathrm{ON}$, the filter capacitor's voltage $V_{C 3}$ is also equal to the voltage induced in $\mathrm{N}_{\mathrm{S} 1}$ andN $\mathrm{N}_{\mathrm{S} 2}$. Thus, voltages $\mathrm{V}_{\mathrm{C} 2}$ and $\mathrm{V}_{\mathrm{C} 3}$ can be is mathematically given as:

$\mathrm{V}_{\mathrm{C} 2}=\mathrm{V}_{\mathrm{C} 3}=\mathrm{n} \cdot \mathrm{V}_{\mathrm{in}}\left(1+\frac{\mathrm{D}}{1-\mathrm{D}}\right)=\frac{\mathrm{n}}{1-\mathrm{D}} \mathrm{V}_{\mathrm{in}}$

The voltage across the output can be derived from

$$
\mathrm{V}_{\mathrm{O}}=\mathrm{V}_{\mathrm{c} 1}+\mathrm{V}_{\mathrm{c} 2}+\mathrm{V}_{\mathrm{c} 3}=\frac{2 \mathrm{n}+4}{1-\mathrm{D}} \mathrm{V}_{\mathrm{in}}
$$

The voltage step up ratio of the proposed converter is ,

$$
\frac{\mathrm{v}_{\mathrm{o}}}{\mathrm{v}_{\mathrm{in}}}=\frac{2 \mathrm{n}+4}{1-\mathrm{D}}
$$




\subsection{Voltage Stress on Switches}

The stress across the semiconductor switches are given as,

$$
\mathrm{V}_{\mathrm{S} 1}=\mathrm{V}_{\mathrm{S} 2}=\frac{2}{1-\mathrm{D}} \mathrm{V}_{\text {in }} \quad=\frac{1}{2 n+4} V_{o}
$$

From the above equation it is shown that a MOSFET with low voltage rating with less $\operatorname{RDS}_{\text {on }}$ can be employed to reduce the conduction losses. The voltage stress across the switch is reduced to one sixth even if the $\mathrm{n}$ is one. This considerable reduction in the conduction losses makes the proposed converter highly employable.

\subsection{Voltage stress on diodes} $\mathrm{V}_{\mathrm{s} 2}$

The voltage stress on the diodes is equal to $\mathrm{Vc1}$ derived as, $\mathrm{V}_{\mathrm{D}(\mathrm{c} 1 \text { \& c2) }}=\mathrm{V}_{\mathrm{cl}}$, which is equal to $\mathrm{V}_{\mathrm{s} 1}$ or

$$
\mathrm{V}_{\mathrm{Dc} 1}=\mathrm{V}_{\mathrm{Dc} 2}=\frac{2}{1-\mathrm{D}} \mathrm{V}_{\mathrm{in}}=\frac{1}{2 \mathrm{n}+1} \mathrm{~V}_{\mathrm{o}}
$$

For a turns ratio of 1 the voltage stress across the diodes is reduced to more than half of the output voltage. The stress on diode $D_{b}$ is approximately equal to the stress on the switches and is derived as,

$\mathrm{V}_{\mathrm{Db} 1}=\mathrm{V}_{\mathrm{Db} 2}=\mathrm{V}_{\mathrm{C} 1}=\mathrm{V}_{\mathrm{C} 2}=\frac{2}{1-\mathrm{D}} \mathrm{V}_{\mathrm{in}}=\frac{1}{2 \mathrm{n}+4} \mathrm{~V}_{0}$

Similarly the stress on diode $\mathrm{D}_{\mathrm{f}}$ is

$V_{D f 1}=V_{D f 2}=V_{c 2}+V_{c 3}=\frac{2 n V_{i n}}{(1-D)}=\mathrm{V}_{\mathrm{Dc} 1}$

when $n$ is 1

As the turns ratio increases the voltage stress on the diodes $D_{f}$ increases but is always less than the output voltage [11].

\subsubsection{Selection of Capacitance and Inductance}

The capacitance value is calculated from the following expression,

$\mathrm{C}=\frac{\mathrm{V}_{\mathrm{O}} \mathrm{DF}}{\mathrm{R} \Delta \mathrm{V}_{\mathrm{O}}}$

Where, $\mathrm{V}_{\mathrm{o}}$ the output voltage $(\mathrm{V}), \mathrm{D}$ the duty ratio, $\mathrm{F}$ frequency $(\mathrm{Hz}), \mathrm{R}$ resistance $(\Omega)$ and $\Delta \mathrm{V}_{\mathrm{O}}$ represents the change in the output voltage $(\mathrm{V})$.

The inductance value is given by

$\mathrm{L}=\mathrm{V}_{\mathrm{in}} *\left(\mathrm{~V}_{\mathrm{o}}-\mathrm{V}_{\mathrm{in}}\right)$

Where Current ripple ,

$$
\overline{\Delta \mathrm{L}}_{\mathrm{L}}^{* \mathrm{~F}_{\mathrm{S}} * \mathrm{~V}_{\mathrm{O}}}
$$

$$
\Delta \mathrm{I}_{\mathrm{L}}=(0.2 \text { to } 0.4) * \mathrm{I}_{\text {OUTMAX }} * \mathrm{~V}_{\mathrm{O}} / \mathrm{V}_{\text {in }}
$$

In this section, an interleaved boost converter with modified voltage multiplier is discussed. In the proposed system the voltage multiplier is been replaced by an $\mathrm{N}$-stage voltage multiplier. By adding $\mathrm{N}$-stage voltage multiplier to the existing converter gives the multiple of output voltage of interleaved converter with voltage multiplier. For example, for 2 -stage voltage multiplier is implemented to converter gives double output voltage of converter. 


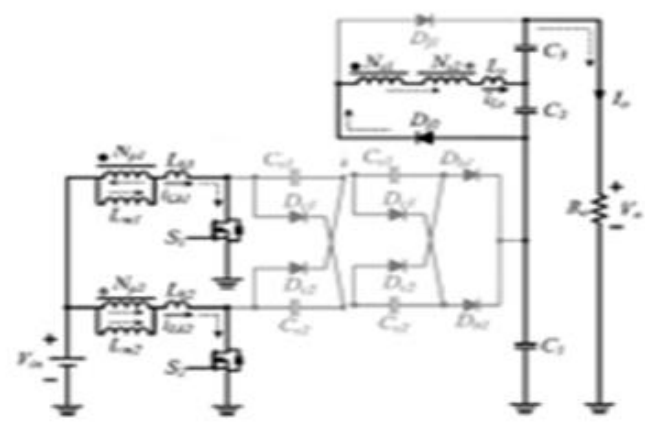

(a) MODE I

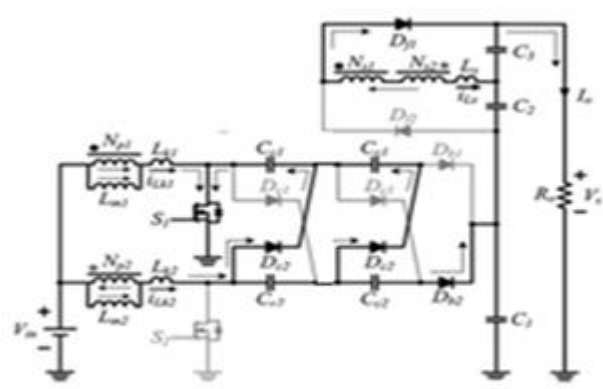

(c) MODE III

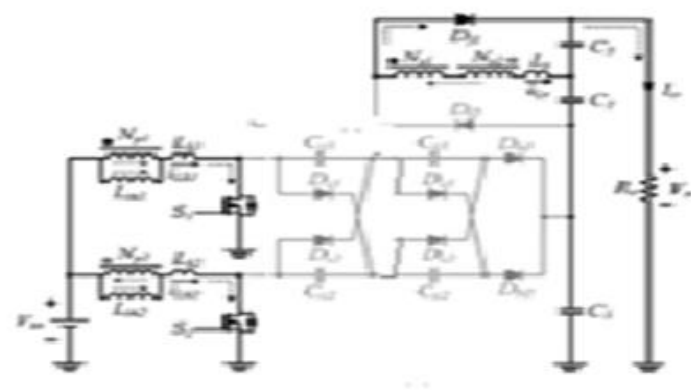

2) MMODE V

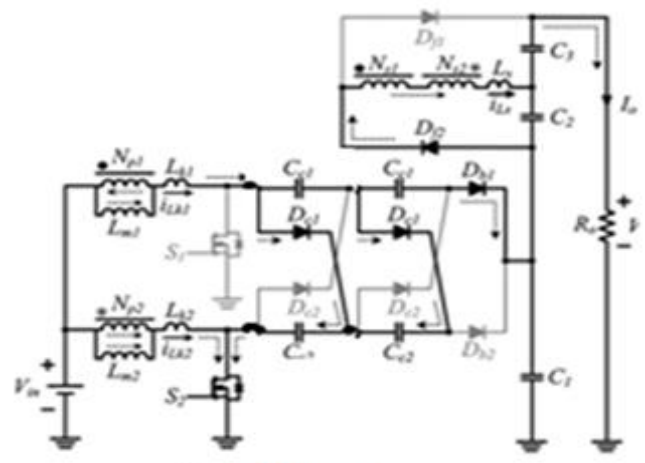

(g) MODE VII

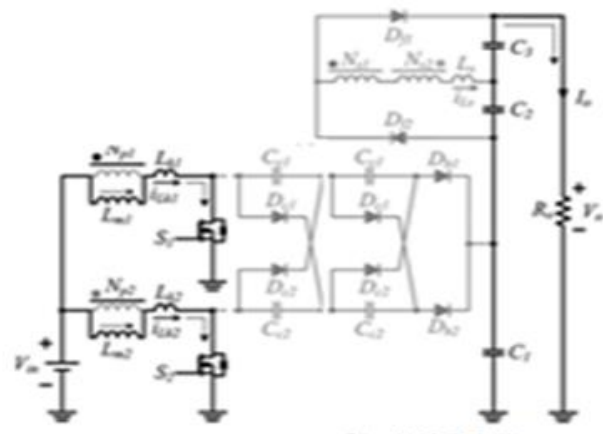

(b) MODE II

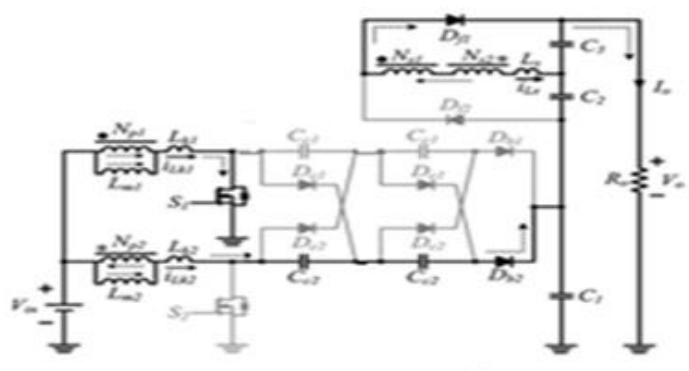

(d) MODE IV

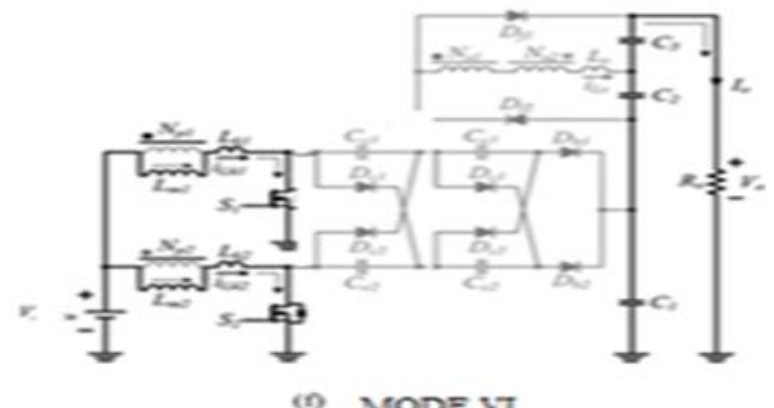

(n) MODE VT

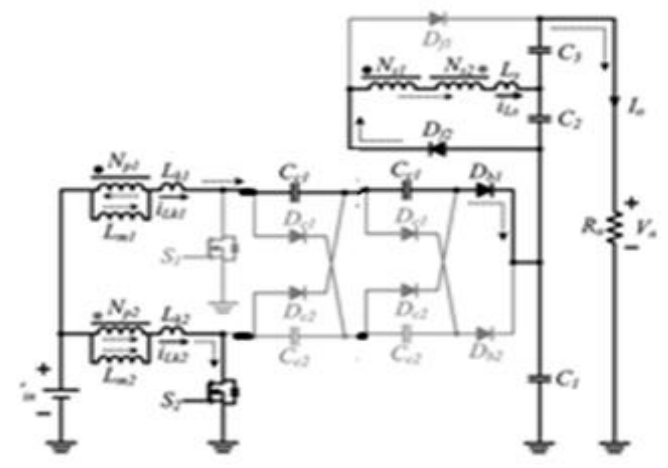

(b) MODE VIII

Figure 3. Operating modes of high gain interleaved boost converter with modified voltage multiplier

\section{SIMULATION AND RESULTS}

The proposed converter topology is simulated using MATLAB which is shown in Figure 4. The input voltage is $28 \mathrm{~V}$ and output voltage is $382 \mathrm{~V}$, thereby the gain is 13 Figure 4 is the Simulation Circuit of Proposed converter in MATLAB. 


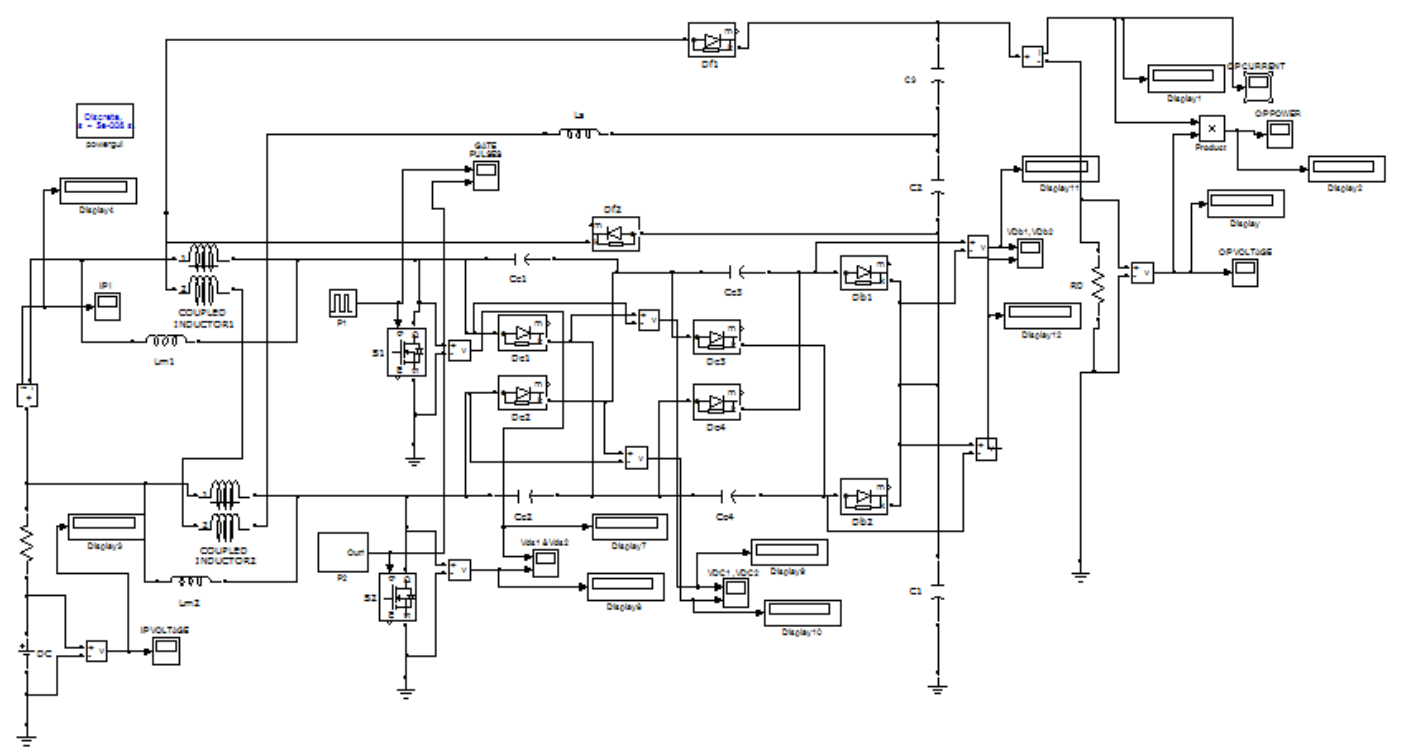

Figure 4. Interleaved Boost Converter with modified voltage multiplier

\subsection{Input Voltage}

Figure 5 shows an input voltage of $28 \mathrm{~V}$ given as input to the proposed converter.

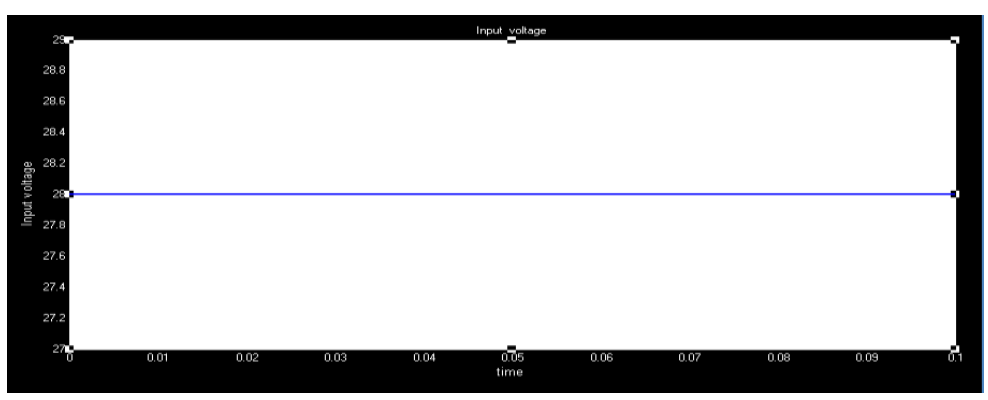

Figure 5. Input voltage $28 \mathrm{~V}$

\subsection{Voltage Across The Switches}

Figure 6 shows the voltages across the main switches $S_{1}$ and $S_{2}$ of interleaved converter with voltage multiplier as $131.4 \mathrm{~V}$.

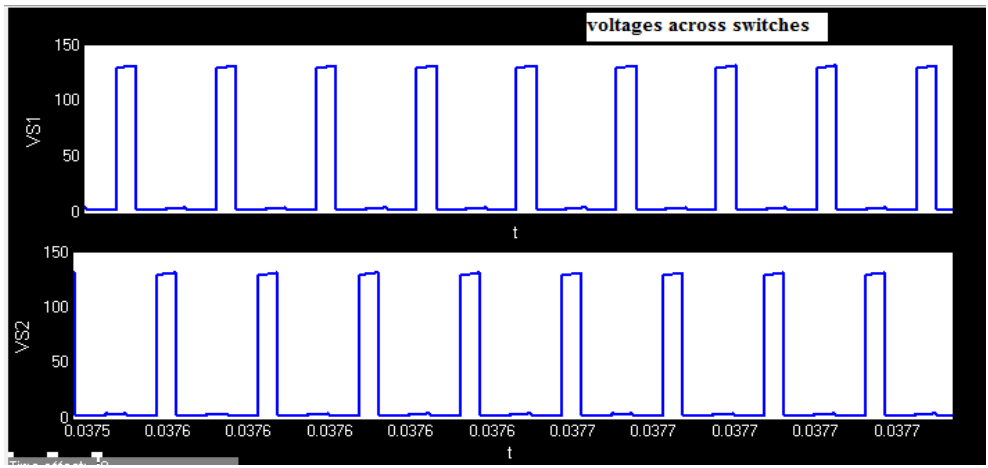

Figure 6. Voltages across the switches 


\subsection{Voltage Across Diodes}

Figure 7 shows the simulated output waveforms of voltages across the clamping diodes.

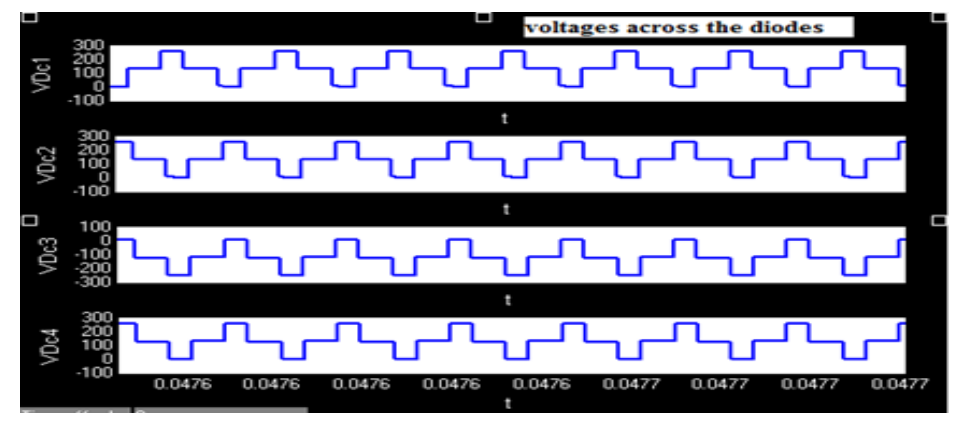

Figure 7. Voltages across the clamping diodes

\subsection{Output Voltage}

Figure 8 shows the output waveform of converter and output voltage as $382 \mathrm{~V}$.

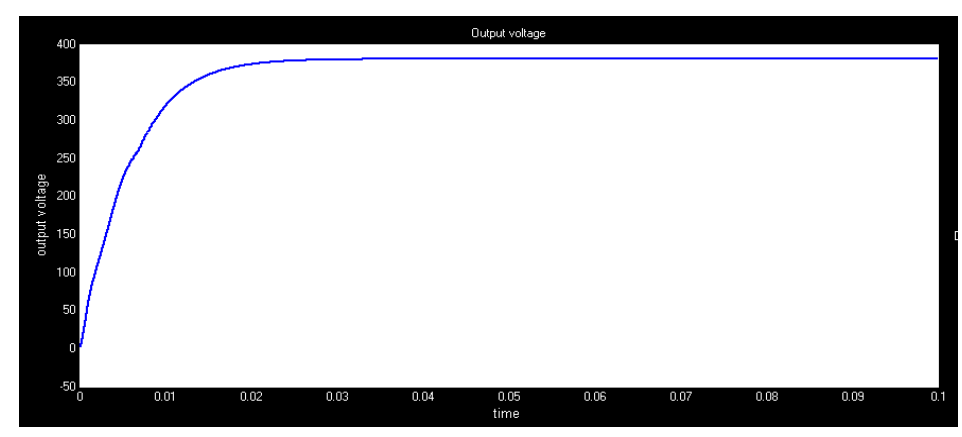

Figure 8. Output voltage of proposed converter

\section{CONCLUSION}

In this paper an interleaved high gain DC-DC Boost Converter with a modified Voltage Multiplier is presented with mathematical analysis and the simulation results. The simulation results shows that for a an input voltage of $28 \mathrm{~V}$ the output Voltage is $382 \mathrm{~V}$ with a duty cycle maintained at 0.65 . The switching frequency is at $40 \mathrm{~Hz}$. The gain is calculated as 13 . The voltage stress across the switches is 131.4 which is approximately equal to $1 / 3^{\text {rd }}$ of the output voltage. Hence the voltage stress across the switch is reduced. The proposed converter has a very high step-up conversion gain of 13 through the voltage multiplier module.The interleaved structure reduces the input current ripple and distributes the current through each component. In addition, clamping capacitors does the function of recycling the leakage energy thus reducing the voltage stress across the power electronic switches.

\section{REFERENCES}

[1] Ahmad Alzahrani, PouryShamsi and Mehdi Ferdowsi”. A Novel Interleaved Non-isolated High Gain DC-DC Boost converter with Greinacher Voltage Multiplier Cells". International conference on Renewable Energy Research and Applications.San Diego,CA,USA,Nov.5-8 2017

[2] Sheshidhar Reddy Addula, M. Prabhakar "A Soft Switched Interleaved High Gain DC-DC Converter".Journal of Engineering Science and Technology Vol. 12, No. 9 (2017) 2346 - 2359.

[3] GetzialAnbu Mani p.,Dr.A.K.Parvathy" Comparitive study of DC-DC Boost Converter for Renewable Energy System".International journal of Applied Engineering Research, ISSN 0973-4562 Vol, 10 No 77(2015) 491-497.

[4] Chitra.P and Seyezhai.R, "Basic Design and Review of Two Phase and Three Phase Interleaved Boost Converter for Renewable Energy Systems” International Journal of Applied Science (ISSN: 2394-9988) [1][1]2014 001-026 
[5] MounicaGanta, PallamreddyNirupa, ThimmadiAkshitha, Dr.R. Seyezhai "Simple And Efficient Implementation Of Two-Phase Interleaved Boost Converter For Renewable Energy Source:" International Journal of Emerging Technology and Advanced Engineering (ISSN 2250-2459, Volume 2, Issue 4, April 2012)

[6] Dr.R.Seyezhai, K.Kaarthika, S.Dipika Shree, MadhuvanthaniRajendran"Design and simulation of a soft switched interleaved flyback converter for fuel cells" International Journal of Management, IT and Engineering

[7] D.Kanimozhi1, K.Balakrishna."A Comparative Study on Various Dc-Dc Converter Configurations for Industrial Drives", International Journal for Research and Development in Engineering (IJRDE)

[8] Ahmad Saudi Samosir1, Taufiq, AbdJaafarShafie, Abdul HalimMohdYatim“Simulation and Implementation of Interleaved Boost DC-DC Converter for Fuel Cell Application"

[9] Studies of interleaved dc-dc boost converters with coupled inductors James Scofield, Seana McNeal, Brett Jordan AFRL-RZPE Hiroyuki Kosai UES, Inc. Biswajit Ray, Bloomsburg University April 2011,Final Report

[10] Sarah Ben Abraham, RiyaScaria "High Step- Up Dc-Dc Converter With Voltage Multiplier Module" Proceedings of Second IRF International Conference on 10th August 2014, Cochin, India

[11] Anjali.R.Prakash "Review of High Step up Converter with Voltage Multiplier for Photovoltaic System " International Journal of Advanced Research in Electrical, Electronics and Instrumentation Engineering. Vol.3, Issue 8, August 2014

[12] Kuo-Ching and Chi-ChihHuang,"High Step up High Efficiency Interleaved Converter with Voltage Multiplier Mdule for Renewable Energy Systems"IEEE transactions in Industrial Electronics, VOL.61,No 3, March 2014. 